\title{
Idiopathic pulmonary fibrosis: current treatment options and critical appraisal of nintedanib
}

This article was published in the following Dove Press journal:

Drug Design, Development and Therapy

14 December 2015

Number of times this article has been viewed

\section{Francesco Bonella' \\ Susanne Stowasser ${ }^{2}$ \\ Lutz Wollin ${ }^{3}$}

'Interstitial and Rare Lung Disease Unit, Ruhrlandklinik, University Hospital, University of DuisburgEssen, Essen, ${ }^{2}$ Boehringer Ingelheim Pharma GmbH \& Co. KG, Ingelheim am Rhein, ${ }^{3}$ Boehringer Ingelheim Pharma GmbH \& Co. KG, Biberach an der Riss, Germany
Correspondence: Lutz Wollin Boehringer Ingelheim Pharma GmbH \& Co. KG, Birkendorfer Strasse 65, 88397 Biberach an der Riss, Germany Tel +49 735I 5494993

Fax +49 735I 8394993

Email stefan-lutz.wollin@boehringeringelheim.com

\begin{abstract}
Idiopathic pulmonary fibrosis (IPF) is the most common type of idiopathic interstitial pneumonia and is characterized by a poor prognosis, with an estimated 5-year survival of approximately $20 \%$. Progressive and irreversible lung functional impairment leads to chronic respiratory insufficiency with a severely impaired quality of life. In the last 2 decades, novel treatments for IPF have been developed as a consequence of an increasing understanding of disease pathogenesis and pathobiology. In IPF, injured dysfunctional alveolar epithelial cells promote fibroblast recruitment and proliferation, resulting in scarring of the lung tissue. Recently, pirfenidone and nintedanib have been approved for the treatment of IPF, having shown efficacy to slow functional decline and disease progression. This article focuses on the pharmacologic characteristics and clinical evidence supporting the use of nintedanib, a potent small-molecule tyrosine kinase inhibitor, as therapy for IPF. After introducing the mechanism of action and pharmacokinetics, an overview of the safety and efficacy results from the most recent clinical trials of nintedanib in IPF is presented.
\end{abstract}

Keywords: tyrosine kinase, disease progression, treatment outcome, usual interstitial pneumonia, therapeutics

\section{Introduction: epidemiology, diagnosis, and pathogenesis of idiopathic pulmonary fibrosis}

Idiopathic pulmonary fibrosis (IPF) is the most common type of idiopathic interstitial pneumonias, a heterogeneous group of chronic progressive disorders involving primarily the lung parenchyma. IPF mainly occurs in older male adults, on average $60-70$ years old, with a history of smoking. The predominant symptom is shortness of breath, initially only during activity but in advanced disease also at rest. Dry cough is also present, and can heavily affect patients' quality of life. The prognosis of IPF is poor, with a median survival time of 3-5 years from the time of diagnosis. ${ }^{1}$ Epidemiologic data were derived principally from national registries and reports from interstitial lung disease (ILD)/IPF referral centers. In a recent review of the epidemiology of IPF, Hutchinson et $\mathrm{al}^{2}$ reported that the incidence of IPF is increasing worldwide and is similar to that of conditions such as stomach, liver, testicular, and cervical cancer. The overall range of incidence of IPF varies from 0.22 to 93.7 per 100,000 per year worldwide, but excluding old studies and different populations (Asia and South America) is likely to be 2.8-9.3 per 100,000 per year in Europe and North America. ${ }^{2}$ The prevalence of IPF is estimated to be between 200 and 500 cases per 100,000 people. ${ }^{3,4}$

The diagnosis of IPF requires the exclusion of known causes of pulmonary fibrosis and the presence of a typical radiologic and pathologic pattern called usual interstitial pneumonia (UIP). ${ }^{5}$ Radiologically, UIP pattern is characterized by 
subpleural, basal-predominant reticular abnormalities and honeycombing, with or without traction bronchiectasis; the histology shows patchy involvement of the lung parenchyma by fibrosis and honeycombing in a predominantly subpleural/ paraseptal distribution and the presence of fibroblastic foci. ${ }^{5}$ In the presence of a definite UIP pattern on high-resolution computed tomography (HRCT), a typical clinical setting, and after exclusion of systemic disease causing fibrosis, a diagnosis of IPF is usually possible without performing lung biopsy. Bronchoalveolar lavage can be a useful tool to exclude other fibrotic lung diseases presenting with UIP pattern, like hypersensitivity pneumonitis. ${ }^{6}$ In recent years, a new technique for bronchoscopic lung biopsy has been developed using flexible cryo-probes. In patients with suspected diffuse parenchymal lung disease, bronchoscopic cryobiopsy is a promising and minimally invasive approach to obtain lung tissue with high diagnostic yield. ${ }^{7,8}$ In any case, the diagnosis of IPF should be confirmed by a specialist center. It has been demonstrated that the accuracy of the diagnosis of IPF increases with multidisciplinary discussion among pulmonologists, radiologists, and pathologists experienced in the diagnosis of ILD. ${ }^{5}$
Looking at the last 2 decades in the history of IPF, it is clear that the development of new drugs has occurred simultaneously with a growing understanding of disease pathogenesis. IPF is a complex multipathway and multigene disease. The current model regarding the pathogenesis of IPF implies aberrant fibrosis as a consequence of recurrent injury to alveolar epithelial cells in a susceptible host (Figure 1). ${ }^{9,10}$ The excessive deposition of extracellular matrix (ECM), with consequent irreversible lung remodeling and honeycombing, is likely to be the result of different processes. Gene polymorphisms and transcriptional changes provide the background, linked to the inability of epithelial cells to respond appropriately to repetitive microinjuries like infections, chronic aspiration, tobacco, or mechanical stress. ${ }^{11}$ Abnormal telomere shortening, as well as epigenetic mechanisms involving DNA methylation, histone tails modification, and dysregulation of microRNA expression, take place in aging lungs and lead to loss of epithelial integrity and epithelial senescence. ${ }^{9}$ Further susceptibility gene variants have been identified in the gene encoding the toll-interacting protein (TOLLIP), an important regulator of innate immunity, and in the Mucin 5B encoding gene (MUC5B), one of the major gel-forming proteins in human airway secretions. ${ }^{11}$

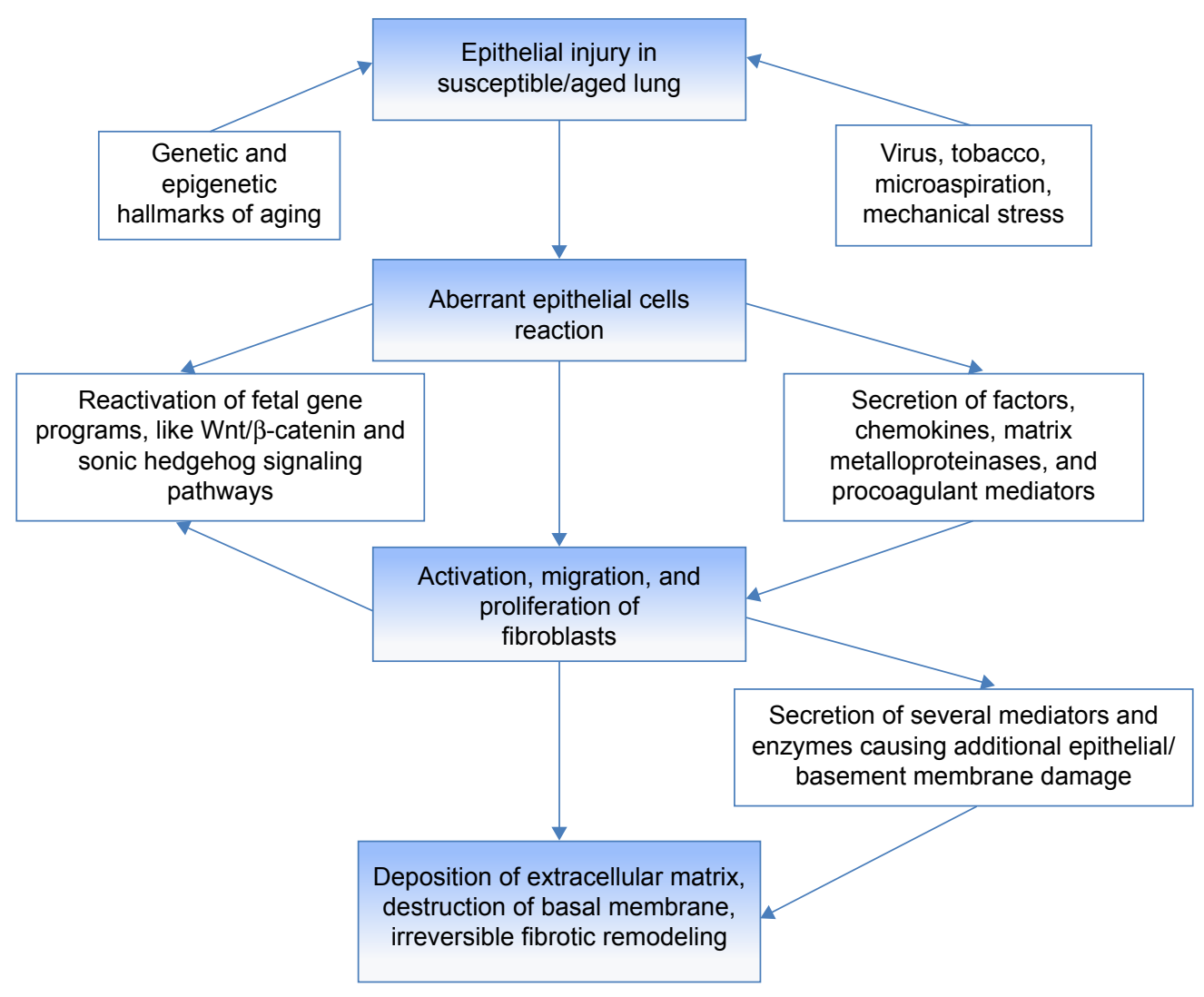

Figure I Schematic representation of the pathogenetic mechanisms underlying IPF. Abbreviation: IPF, idiopathic pulmonary fibrosis. 
Interestingly, individuals with the susceptibility MUC5B rs35705950_T allele or the major TOLLIP rs5743890_A allele who develop IPF seem to have decreased mortality. ${ }^{12,13}$

In an attempt to restore functional integrity, injured Type II alveolar epithelial cells aberrantly release pleonastic cytokines and growth factors, matrix metalloproteinases (MMPs), and procoagulant mediators, which promote the recruitment and activation of apoptosis-resistant fibroblasts, the key players in fibrotic tissue remodeling. ${ }^{9,10}$ Fibroblasts/myofibroblasts secrete several mediators and enzymes that provoke additional epithelial/basement membrane damage and perpetuate the aberrant wound healing response. Senescence of the immune system (production of autoantibodies, increased expression of toll-likereceptor, ${ }^{9}$ downregulation of specific subtypes of T-cells) has been proposed as one of the most important factors inducing progression of IPF. ${ }^{10} \mathrm{An}$ increase in several microRNAs and noncoding RNAs influencing gene expression and a decrease in Argonaute (AGO)-1 and AGO2, which are indispensable for miRNA processing, have been revealed in lungs from patients with IPF with rapid progression in comparison to patients with stable IPF. ${ }^{9} 10$ Identifying signatures of disease progression, through circulating proteins alone or in combination, specific genotypes of single nucleotide polymorphisms, or epigenetic biomarkers, will be crucial to develop better stratification tools for patients and drive therapeutic decisions targeted to individual profiles. The knowledge deriving from translational biomarkers research will provide an important source of targets for drug development, because such proteins are seldom only an epiphenomenon. ${ }^{14}$ However, one of the major problems in developing new treatments for IPF is the remarkable redundancy of the pathways involved in its pathogenesis. Similar to cancer, inhibiting single mediators or signaling pathways is largely ineffective in reducing the progression of IPF. ${ }^{15}$

\section{Management of IPF}

The therapeutic approach for IPF integrates both nonpharmacologic and pharmacologic strategies. ${ }^{5,15}$ The goals of treatment in IPF are essentially to stop disease progression, reduce symptoms, prevent acute exacerbations - a life-threatening complication occurring in approximately $5 \%-15 \%$ of patients $^{16,17}$ - and finally prolong survival. Preventive care, rehabilitation, and symptom-based treatment should be started early in every patient to fight decline in quality of life. ${ }^{18,19}$ Inactivity due to shortness of breath leads to loss of muscular mass (sarcopenia) and chronic disabling fatigue in patients with IPF. Pulmonary rehabilitation may not only alleviate symptoms by reducing the threshold of dyspnea, but also improve functional status by stabilizing and/or reversing the extrapulmonary features of the disease. ${ }^{15,20}$ Patients should be referred to rehabilitation as standard of care as soon as possible after diagnosis, before the impact of symptoms on health-related quality of life becomes irreversible. ${ }^{21,22}$ Long-term oxygen treatment is essential for patients with resting or nocturnal hypoxemia. ${ }^{5,23}$ Although there are no data from randomized clinical trials on the utility of oxygen treatment in IPF, it has been demonstrated that oxygen therapy may improve quality of life by impacting physical and social performance. ${ }^{23}$

Lung transplantation is an established therapeutic option for chronic lung diseases, but patients with IPF represent only $35 \%$ of transplant recipients. ${ }^{24}$ In patients with IPF, lung transplant has been shown to reduce the risk of death by $75 \%$ compared with patients who remain on the waiting list. ${ }^{25}$ Fiveyear survival rates range from $50 \%$ to $56 \%$, with transplanted patients with IPF appearing to have more favorable long-term survival than those transplanted for other indications. ${ }^{26}$ The efficacy of single- or double-lung transplantation in patients with IPF is still under debate. In a recently published exploratory analysis of transplant registry data from the USA, double-lung transplantation was associated with better graft survival (median: 65 months) than single-lung transplantation (50 months, $P<0.001$ ) in 4,134 patients with IPF. ${ }^{27}$

In recent years, the landscape of pharmacologic treatment of IPF has completely changed. On the one hand, the definitive results of the PANTHER-IPF trial, a randomized, three-arm trial of prednisone, azathioprine, and $N$-acetylcysteine (NAC) in combination, NAC alone, or placebo, showed no effect of NAC monotherapy on the rate of change in forced vital capacity (FVC) in patients with IPF over a 60 -week period..$^{28}$ On the other hand, the efficacy of the two antifibrotic molecules pirfenidone (Esbriet ${ }^{\circledR}$, manufactured by F. Hoffmann-La Roche AG, Basel, Switzerland) and nintedanib (Ofev ${ }^{\circledR}$, manufactured by Boehringer Ingelheim Pharma GmbH \& Co. KG, Ingelheim, Germany) in slowing the progression of IPF was confirmed by the Phase III ASCEND trial ${ }^{29}$ and the twin Phase III INPULSIS- 1 and -2 trials, ${ }^{30}$ respectively. On the basis of the results of these trials, in patients with IPF and mild or moderate impairment in FVC, both pirfenidone and nintedanib reduce decline in FVC by approximately $50 \%$ in 1 year, with acceptable safety profiles. This led to the approval of both medications for the treatment for IPF in the USA in 2014 and to the approval of nintedanib in Europe at the beginning of 2015 (pirfenidone had already been approved in Europe). Because of the slightly different study populations included in the trials of nintedanib and pirfenidone, it would be imprudent to compare these trials to contrast the efficacy of these agents. The recently updated ATS/ERS/JRS/ALAT 
clinical practice guideline gives conditional recommendations for the use of nintedanib and pirfenidone in the majority of patients with IPF. ${ }^{31}$ No head-to-head studies comparing nintedanib and pirfenidone have been conducted, and the new recommendations did not recommend one treatment over the other. ${ }^{31}$ Rather, the guideline emphasizes the need to consider individual patients' values and preferences in making treatment decisions. Potential side effect profiles, comorbidities, and lifestyle should also be taken into account.

Pirfenidone is a small molecule with antifibrotic and antiinflammatory properties. ${ }^{32,33}$ Its safety and efficacy have been evaluated in five randomized clinical trials in a total of 1,710 patients..$^{29,34-36}$ The ASCEND trial, in which 555 patients with IPF were randomized to receive either the maximum oral dose of pirfenidone $(2,403 \mathrm{mg} / \mathrm{d})$ or placebo, confirmed that pirfenidone significantly reduced $\mathrm{FVC}$ decline from baseline to week 52. Pirfenidone also significantly reduced the decline in 6-minute walk test (6MWT) distance and reduced disease progression, defined as an absolute decrease in $\mathrm{FVC} \%$ predicted of $\geq 10 \%$ and/or a decrease in $6 \mathrm{MWT}$ distance of $\geq 50 \mathrm{~m}$ or death by $43 \%$ compared with placebo. The most frequent side effects associated with pirfenidone are gastrointestinal and skin related, including photosensitivity reactions and skin rash. ${ }^{29,35}$

\section{Specific considerations for potential combination therapy in IPF}

In various respiratory diseases such as asthma, chronic obstructive pulmonary disease, pulmonary hypertension, and lung cancer, combination regimens have been successfully established. With two antifibrotic drugs available for the treatment of IPF, it might be a logical next step to combine pirfenidone and nintedanib to obtain synergistic effects. In a randomized, double-blind, Phase II, dose escalation trial to assess the safety, tolerability, and pharmacokinetics of nintedanib in 50 Japanese patients with IPF stratified by preexisting pirfenidone treatment, a trend toward lower exposure of nintedanib was observed when nintedanib was added to pirfenidone compared to when it was given alone. ${ }^{37}$ Although this study provides first data on concomitant treatment with nintedanib and pirfenidone, no conclusions on safety and efficacy can be drawn due to the low number of patients and the limited treatment duration (maximum of 28 days). Concomitant treatment with nintedanib and pirfenidone cannot be recommended until there are data to demonstrate its efficacy and tolerability/safety in patients with IPF.

\section{Clinical pharmacokinetics of nintedanib}

The clinical pharmacokinetics of nintedanib (formerly known as BIBF 1120) have been studied in healthy volunteers, ${ }^{38}$ and in patients with cancer or IPF in a number of Phase $\mathrm{I}^{39-46}$ and $\mathrm{II}^{37,47,48}$ clinical trials as monotherapy and in combination with other agents. After oral administration, nintedanib is rapidly absorbed. After 1-3 hours, maximum plasma concentration $\left(C_{\text {max }}\right)$ is achieved. ${ }^{38,40}$ The mean terminal half-life of nintedanib is $13-28$ hours. ${ }^{37,38,40}$ Overall drug exposure of nintedanib (area under the plasma concentration-time curve [AUC]) show dose-proportional increases. ${ }^{40}$ No decrease in exposure was observed over a minimum 6-month treatment period. ${ }^{40}$ Following multiple twice-daily administration of nintedanib, only slight accumulation of nintedanib exposure was observed, with a mean accumulation ratio of 1.66 based on $\mathrm{AUC}_{0-12 \mathrm{~h}}$ and 1.33 based on $C_{\max }{ }^{49}$ The mean $C_{\max }$ at steady state at the standard dosing in IPF of $150 \mathrm{mg}$ twice daily is in the range of $35-40 \mathrm{ng} / \mathrm{mL}$, which is approximately 64-74 nmol/L (FW =539.62 $\mathrm{g} / \mathrm{mol}){ }^{37,40}$ Interpatient variability of parameters for nintedanib is moderate to high. ${ }^{38,40,49}$ The apparent volume of distribution of nintedanib during the terminal phase is high, indicating a high tissue distribution of the drug and a high apparent total body clearance. ${ }^{38}$ The major route of nintedanib elimination is through metabolism, with metabolites excreted via the biliary system into the feces. Urinary excretion for nintedanib is minor. ${ }^{38}$ The metabolism of nintedanib has been explored in healthy volunteers. Nintedanib is cleaved at the methyl ester moiety, resulting in a carboxylate, which is then conjugated to glucuronic acid and in a further step to the 1-O-acylglucuronide. Hence, the metabolism of nintedanib is mainly CYP450 enzyme independent. ${ }^{50}$

\section{Mechanism of action in IPF}

Nintedanib is a potent small-molecule receptor tyrosine kinase inhibitor targeting platelet-derived growth factor receptor (PDGFR) $\alpha$ and $\beta$ ( $\mathrm{IC}_{50}$ [half maximal inhibitory concentration] $=59$ and $65 \mathrm{nmol} / \mathrm{L})$; fibroblast growth factor receptor (FGFR)-1, -2, -3 , and $-4\left(\mathrm{IC}_{50}=69,37,108\right.$, and $610 \mathrm{nmol} / \mathrm{L})$; and vascular endothelial growth factor receptor (VEGFR)-1, -2, and $-3\left(\mathrm{IC}_{50}=34,21\right.$, and $\left.13 \mathrm{nmol} / \mathrm{L}\right){ }^{51}$ Nintedanib binds competitively to the ATP binding pocket of these receptors and so blocks intracellular signaling. Nintedanib also inhibits the proto-oncogene tyrosine-protein kinase $\mathrm{Src}\left(\mathrm{IC}_{50}=156 \mathrm{nmol} / \mathrm{L}\right)$, lymphocyte-specific tyrosineprotein kinase $\mathrm{Lck}\left(\mathrm{IC}_{50}=16 \mathrm{nmol} / \mathrm{L}\right), \mathrm{Lck} /$ Yes novel tyrosine kinase Lyn $\left(\mathrm{IC}_{50}=195 \mathrm{nmol} / \mathrm{L}\right)$, and Fms-like tyrosine kinase 3 Flt-3 $\left(\mathrm{IC}_{50}=26 \mathrm{nmol} / \mathrm{L}\right) .{ }^{51}$ Distinct functions that may impact the pathology of IPF have been described for specific tyrosine kinases. However, the exact contribution of inhibition of specific kinases to the activity of nintedanib in IPF has not been established. ${ }^{52}$ 


\section{Role of targeted growth factors in IPF}

PDGF is a potent mitogen for fibroblasts ${ }^{53}$ and is produced by alveolar macrophages and epithelial cells. ${ }^{54,55}$ PDGF appears to play an essential role in the expansion of myofibroblasts by stimulating proliferation, migration, and survival and acts as a stimulator of collagen synthesis. ${ }^{54-58}$ The result is a pathologic remodeled alveolar architecture with deteriorated gas exchange. ${ }^{5,16,59}$ Inhibition of PDGFR with specific compounds reduces pulmonary fibrosis in a variety of animal models. ${ }^{60-64}$

FGFR-1 is expressed on epithelial cells, endothelial cells, smooth muscle cells, myofibroblast-like cells, and macrophages in the lungs of patients with IPF, and FGFR-2 on smooth muscle cells, myofibroblast-like cells, and neutrophils. ${ }^{65} \mathrm{FGF}-2$ stimulates proliferation of lung fibroblasts from patients with IPF. ${ }^{66}$ In vivo abrogation of FGF signaling reduces bleomycin-induced pulmonary fibrosis and improves survival in bleomycin-treated mice. ${ }^{67}$ However, recent reports also describe a protective role of certain FGFs. ${ }^{68-70}$

The role of VEGF signaling in IPF is unclear. VEGF stimulates human lung fibroblast proliferation less potently than FGF or PDGF. ${ }^{71}$ However, anti-VEGF gene therapy attenuates bleomycin-induced fibrosis in mice. ${ }^{72}$ VEGF signaling is a prominent pathway in vascular remodeling, which is a pathologic feature in IPF, but it is controversial whether angiogenesis plays a key role in abnormal ECM remodeling and fibrosis in the lung, ${ }^{73,74}$ and extensive temporal and spatial heterogeneity in angiogenesis has been observed in patients with IPF. ${ }^{75,76}$ The balance between angiostatic and angiogenic mediators in patients with IPF remains controversial. ${ }^{77}$

The roles of these growth factor receptors with respect to potential adverse events are unclear due to a lack of inhibitors specific for single kinases. Although certain so-called "class effects" like gastrointestinal disturbances or liver enzyme elevations have been proposed for VEGFR inhibitors, ${ }^{78}$ such effects vary considerably in frequency and intensity between compounds and are not observed for all VEGFR inhibitors. No consistent pattern of "class effects" can be deduced for the available multispecific PDGFR inhibitors, but their most common side effects appear to be nausea and vomiting. ${ }^{79}$ For FGFR inhibition, hyperphosphatemia seems to be a potential adverse effect. ${ }^{80}$

\section{Nintedanib interferes with fundamental processes in lung fibrosis in a variety of in vitro assays}

Nintedanib has been shown to inhibit growth factor-induced proliferation and migration of primary human lung fibroblasts from patients with IPF (IPF-HLF) or control donors (N-HLF). Depending on the cell type and growth factor used, the $\mathrm{IC}_{50}$ values vary from below 1 to $226 \mathrm{nmol} / \mathrm{L}$ (Table 1 ). Nintedanib inhibited transforming growth factor $\beta$-induced fibroblast to myofibroblast transformation of IPF-HLF, as determined by $\alpha$ smooth muscle actin mRNA expression (Table 1).

Few data are available on the direct activity of nintedanib on ECM secretion in vitro. At high concentrations $(1 \mu \mathrm{mol} / \mathrm{L})$,

Table I Activity of nintedanib in in vitro assays of lung fibrosis

\begin{tabular}{|c|c|c|c|c|}
\hline Cell type & Stimulation & Readout & $\mathrm{IC}_{50}[\mathrm{nmol} / \mathrm{L}]$ & Reference \\
\hline $\mathrm{N}-\mathrm{HLF}$ & PDGF-BB & PDGFR $\alpha / \beta$ phosphorylation & $22 / 39$ & 78 \\
\hline $\mathrm{N}-\mathrm{HLF}$ & PDGF-BB & Proliferation & 64 & 78 \\
\hline $\mathrm{N}-\mathrm{HLF}$ & PDGF-BB & Proliferation & $1-10$ & 71 \\
\hline $\mathrm{N}-\mathrm{HLF}$ & FGF2 & Proliferation & $\sim 1$ & 71 \\
\hline $\mathrm{N}-\mathrm{HLF}$ & VEGF & Proliferation & $<1$ & 71 \\
\hline IPF-HLF & PDGF-BB & Proliferation & $\sim 10$ & 71 \\
\hline IPF-HLF & FGF2 & Proliferation & $1-10$ & 71 \\
\hline IPF-HLF & VEGF & Proliferation & $<1$ & 71 \\
\hline $\mathrm{N}-\mathrm{HLF}$ & IL-I $\beta$ & Proliferation & 106 & 92 \\
\hline IPF-HLF & IL-I $\beta$ & Proliferation & 193 & 92 \\
\hline $\mathrm{N}-\mathrm{HLF}$ & FBS & Proliferation & 13 & 93 \\
\hline $\mathrm{N}-\mathrm{HLF}$ & PDGF-BB & Motility & 19 & 52 \\
\hline $\mathrm{N}-\mathrm{HLF}$ & FGF2 & Motility & 86 & 52 \\
\hline IPF-HLF & PDGF-BB & Motility & 28 & 52 \\
\hline IPF-HLF & FGF2 & Motility & 226 & 52 \\
\hline IPF-HLF & TGF $\beta$ & $\alpha S M A$ expression & 144 & 78 \\
\hline HUVEC & VEGF & Proliferation & 9 & 51 \\
\hline HUVEC & FGF2 & Proliferation & 290 & 51 \\
\hline HSMEC & VEGF & Proliferation & 7 & 51 \\
\hline BRP & PDGF-BB & Proliferation & 79 & 51 \\
\hline HUASMC & PDGF-BB & Proliferation & 69 & 51 \\
\hline
\end{tabular}

Abbreviations: $\mathrm{IC}_{50}$, half maximal inhibitory concentration; N-HLF, primary human lung fibroblasts from control donors; PDGF-BB, platelet-derived growth factor BB; PDGFR, platelet-derived growth factor receptor; FGF2, fibroblast growth factor 2; VEGF, vascular endothelial growth factor; IPF-HLF, primary lung fibroblasts from patients with idiopathic pulmonary fibrosis; IL-I $\beta$, interleukin I beta; FBS, fetal bovine serum; TGF $\beta$, transforming growth factor beta; $\alpha$ SMA, alpha smooth muscle actin; HUVEC, human umbilical vein endothelial cell; HSMEC, human skin microvascular endothelial cell; BRP, bovine retinal pericyte; HUASMC, human umbilical artery smooth muscle cell. 
nintedanib reduced TGF $\beta$-stimulated collagen secretion and deposition by IPF-HLF. Nintedanib also reduced secreted tissue inhibitor of metalloproteinase (TIMP)-2 levels. ${ }^{71}$ However, the enzymatic activity and secretion of MMP-2 were significantly reduced at lower concentrations (approximately 1 and $100 \mathrm{nmol} / \mathrm{L}$, respectively). ${ }^{71}$ Additionally, nintedanib is expected to have indirect activity on ECM secretion and deposition by reducing the number of fibroblasts/ myofibroblasts in fibrotic lungs. Nintedanib attenuated proliferation of cell types involved in neoangiogenesis, endothelial cells, vascular smooth muscle cells, and pericytes, with $\mathrm{IC}_{50}$ values ranging from below 7 to $290 \mathrm{nmol} / \mathrm{L}$ (Table 1).

\section{Antifibrotic and anti-inflammatory activity of nintedanib in animal models of lung fibrosis}

The in vivo efficacy of nintedanib has been explored in three animal models: bleomycin-induced lung fibrosis in mice and rats and silica-induced lung fibrosis in mice. Pharmacokinetic/pharmacodynamic correlation experiments confirmed the effective dose in mice to be in the range of 30-100 mg/kg. ${ }^{81}$ Nintedanib was administered orally, once daily, in both a preventive regimen starting directly after bleomycin or silica stimulation and a therapeutic regimen starting after the onset of fibrotic lung alteration. In general, nintedanib reduced lung inflammation and lung fibrosis across the animal models. The parameters explored and the extent of inhibitory activity differed between models. A daily dose of 30-100 mg/kg nintedanib in mice and $10-50 \mathrm{mg} / \mathrm{kg}$ in rats was efficacious and tolerated when administered for 10-30 days. In summary, nintedanib reduced lung inflammation demonstrated by reduced lymphocyte counts in the bronchoalveolar lavage fluid, interleukin-1 $\beta$, chemokine (C-X-C motif) ligand 1/keratinocyte chemoattractant detected in lung tissue; diminished percentage of myeloid dendritic cells in lung tissue; and semiquantitative histologic analysis of hematoxylin and eosin-stained micrographs of the lungs. Furthermore, nintedanib diminished lung fibrosis demonstrated by reduced TIMP-1 and total collagen levels in lung tissue, by semiquantitative histologic analysis of the lungs and by reduction of mRNA expression of fibrosis-related marker genes (TGF- $\beta 1$; procollagen I).

Recently, nintedanib has been shown to reduce the extent of missing integrity of the vascular architecture and to reduce the increase in vessel density and the diameter of enlarged vessels in bleomycin-induced vascular remodeling in fibrotic mouse lungs $;{ }^{82}$ however, whether this antiangiogenic efficacy adds to its antifibrotic activity in IPF still needs to be elucidated. Nintedanib might also exert acute vasodilatory activity on the pulmonary circulation. The effect of nintedanib on endothelin-1 preconstricted pulmonary vessels was recently explored in precision-cut lung slices and isolated perfused lungs from mice. Nintedanib relaxed the pulmonary arterial bed significantly. ${ }^{83}$ Whether this holds true for human pulmonary vessels remains unknown.

Although substantial preclinical evidence demonstrates that nintedanib has antifibrotic, anti-inflammatory, and antiangiogenic activity, it has not been possible to map specific inhibition of single kinases by nintedanib to precise functional outcomes.

\section{Clinical efficacy, safety, and tolerability of nintedanib Data from Phase II and III clinical trials in IPF}

Nintedanib has been investigated in three international Phase II (TOMORROW) and Phase III clinical trials (INPULSIS ${ }^{\circledR}-1$ and INPULSIS ${ }^{\circledR}-2$ ) including almost 1,500 patients with IPF. ${ }^{30,84}$ These have been followed by open-label extension trials (NCT01170065 and INPULSIS ${ }^{\circledR}$-ON) to provide a treatment option to all patients who completed the TOMORROW or INPULSIS ${ }^{\circledR}$ trials and to assess long-term safety and tolerability. In addition, the Japanese Phase II study that assessed the safety, tolerability, and pharmacokinetic profile of nintedanib when given alone or in addition to preexisting pirfenidone treatment ${ }^{37}$ was followed by an open-label extension trial (NCT01417156; Table 2). Period 1 of the dose-finding TOMORROW trial suggested that 52 weeks' treatment with nintedanib $150 \mathrm{mg}$ bid results in reduced decline in FVC, fewer acute exacerbations, and preservation of health-related quality of life versus placebo. ${ }^{84}$ On the basis of these results and an acceptable safety profile, a dose of nintedanib $150 \mathrm{mg}$ bid, with the option to reduce the dose to $100 \mathrm{mg}$ bid and/or interrupt treatment for the management of adverse events, was chosen as the treatment regimen for the replicate Phase III INPULSIS $^{\circledR}$ trials. In the INPULSIS ${ }^{\circledR}$ trials, 1,066 patients from 24 countries were randomized in a 3:2 ratio to 52 weeks of treatment with nintedanib or placebo. ${ }^{30}$ As in the TOMORROW trial, the primary end point was the annual rate of decline in FVC as a measure of disease progression. Key secondary end points were change in total score on the St George's Respiratory Questionnaire (SGRQ) over 52 weeks and time to first investigator-reported acute exacerbation. Acute exacerbations adjudicated as confirmed or suspected acute exacerbations in pooled data from both trials was a prespecified sensitivity analysis. On the basis of inclusion and exclusion criteria, 


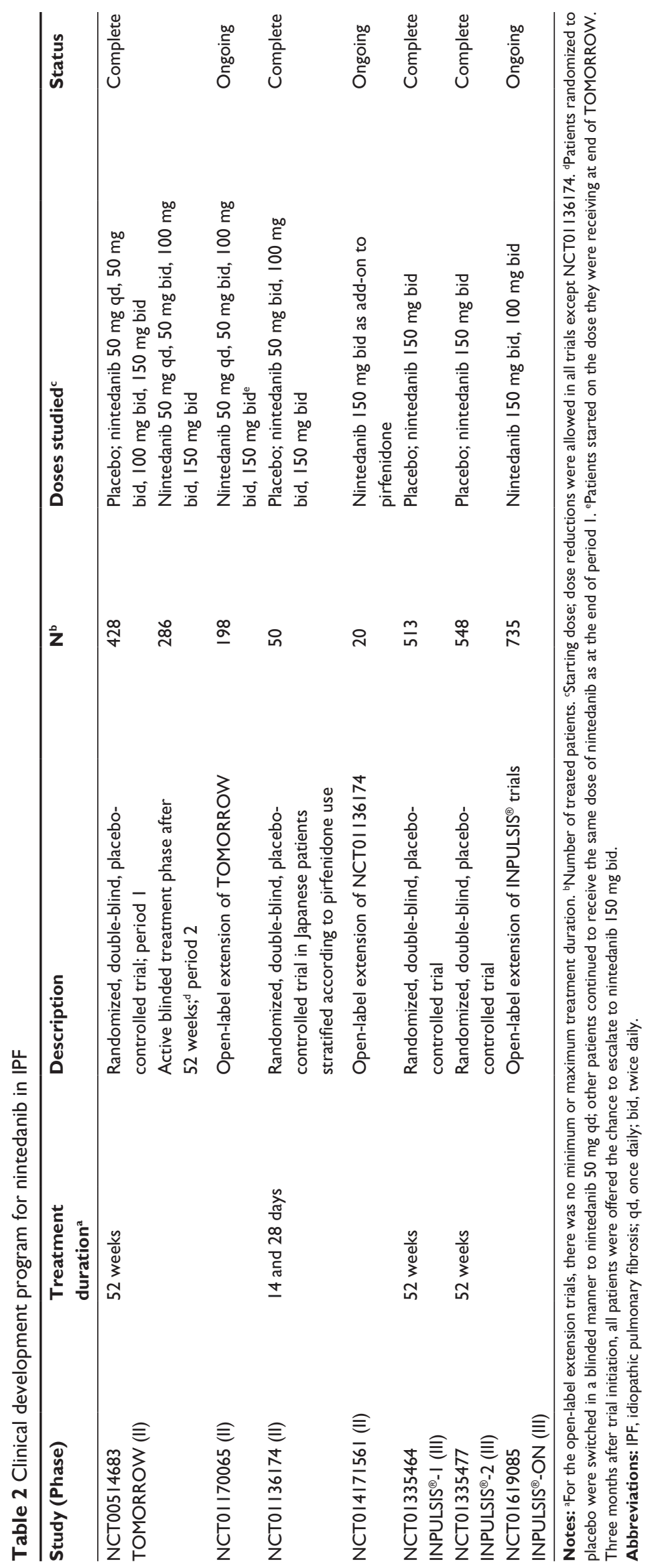


a broad range of patients was eligible, including patients with radiologic emphysema, ${ }^{85}$ patients with mild FVC impairment at baseline, ${ }^{86} \mathrm{ie}, \mathrm{FVC}>90 \%$ predicted, and patients with features of possible UIP on HRCT scans without surgical biopsy. ${ }^{87}$

In both INPULSIS ${ }^{\circledR}$ trials, the primary outcome was achieved, with a reduction in the annual rate of FVC decline of approximately $50 \%$ in the nintedanib group compared to placebo. In a pooled analysis of data from the two trials, the adjusted annual rate of decline in FVC was $114 \mathrm{~mL}$ in the nintedanib group versus $224 \mathrm{~mL}$ in the placebo group (mean difference $110 \mathrm{~mL} / \mathrm{yr}, P<0.001$; Figure 2). The robustness and consistency of the results on the primary outcome were confirmed in a number of sensitivity analyses, ${ }^{88}$ across outcomes for changes in FVC (change from baseline, categorical changes), ${ }^{89}$ across various prespecified ${ }^{90}$ and post hoc subgroup analyses, eg, defined by radiologic presence/ absence of emphysema, ${ }^{85}$ by baseline FVC \% predicted ( $\leq 90 \%$ versus $>90 \%)^{86}$ and by HRCT diagnostic criteria (honeycombing on HRCT and/or confirmation of diagnosis by biopsy versus patients with features of possible UIP on HRCT and no biopsy; Figure 3). ${ }^{87}$ Furthermore, the effect of nintedanib on slowing the decline in FVC in patients with IPF was maintained up to week 76 during period 2 of the TOMORROW trial ${ }^{91}$ and supported by a numerical risk reduction in all-cause mortality of $30 \%$ (HR [hazard ratio $=0.70 ; P=0.095$ ) in a pooled analysis of data from the TOMORROW and INPULSIS ${ }^{\circledR}$ trials. $^{92}$
Nintedanib significantly reduced the risk of a first investigator-reported acute exacerbation versus placebo in INPULSIS $^{\circledR}-2(\mathrm{HR}=0.38 ; P<0.01)$, but there was no difference in INPULSIS ${ }^{\circledR}-1(\mathrm{HR}=1.15 ; P=0.67)$. In the prespecified sensitivity analysis based on adjudicated confirmed or suspected acute exacerbations, there was a statistically significant difference in favor of nintedanib, with a reduction in risk of $68 \%(\mathrm{HR}=0.32 ; P<0.01) .{ }^{30}$ In various prespecified and post hoc subgroup analyses based on pooled data from both trials, the treatment effect of nintedanib on time to first investigator-reported acute exacerbation was generally similar. ${ }^{85-87,90}$ A more pronounced treatment effect was seen in patients with more advanced restrictive lung disease (FVC $\leq 70 \%$ predicted at baseline) in whom the majority of events were observed; investigator-reported acute exacerbations occurred in $7.7 \%$ and $14.9 \%$ of nintedanib- and placebo-treated patients with baseline $\mathrm{FVC} \leq 70 \%$ predicted, and in $3.5 \%$ and $3.3 \%$ of nintedanib- and placebo-treated patients with baseline FVC $>70 \%$ predicted, respectively (Figure 4). ${ }^{90}$ The mean difference in change from baseline in SGRQ total score at week 52 was -2.69 points in INPULSIS $^{\circledR}-2(P<0.02)$ and -0.05 points in INPULSIS $^{\circledR}-1$ $(P=0.97)$, in favor of nintedanib, resulting in a numerical difference of -1.43 points in the pooled data set $(P=0.09)$, which was consistent across subgroups. ${ }^{85-87,90}$

The most frequently reported adverse event in the INPULSIS ${ }^{\circledR}$ trials was diarrhea, which was reported in $62 \%$

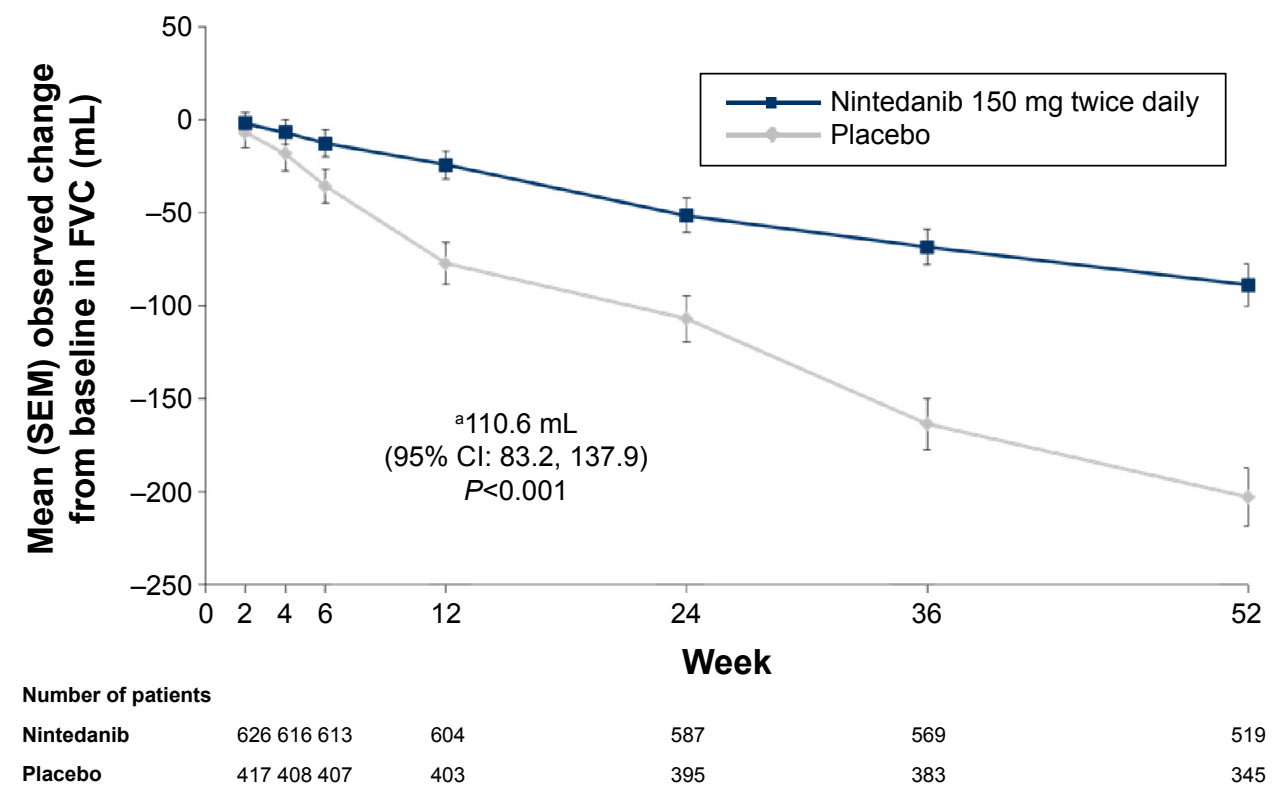

Figure 2 Mean (SEM) observed change from baseline FVC $(\mathrm{mL})$ over time in pooled data from the INPULSIS ${ }^{\circledR}$ trials.

Notes: aAdjusted mean difference versus placebo at week 52 based on mixed model repeated measures. From N Engl J Med, Richeldi L, du Bois RM, Raghu G, et al, Efficacy and safety of nintedanib in idiopathic pulmonary fibrosis, Volume 370, Pages 207I-2082. Copyright @20I4, Massachusetts Medical Society. Reprinted with permission from Massachusetts Medical Society. ${ }^{30}$

Abbreviations: SEM, standard error of mean; FVC, forced vital capacity; Cl, confidence interval. 


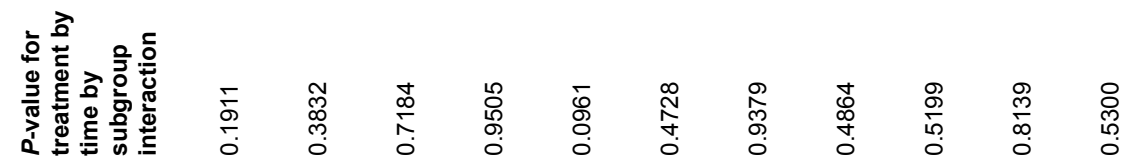

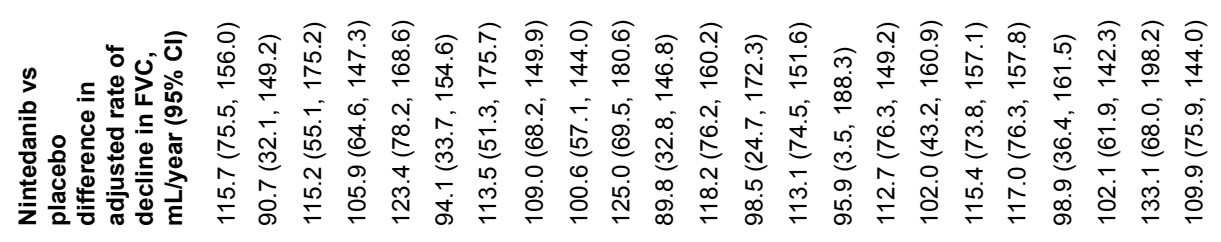

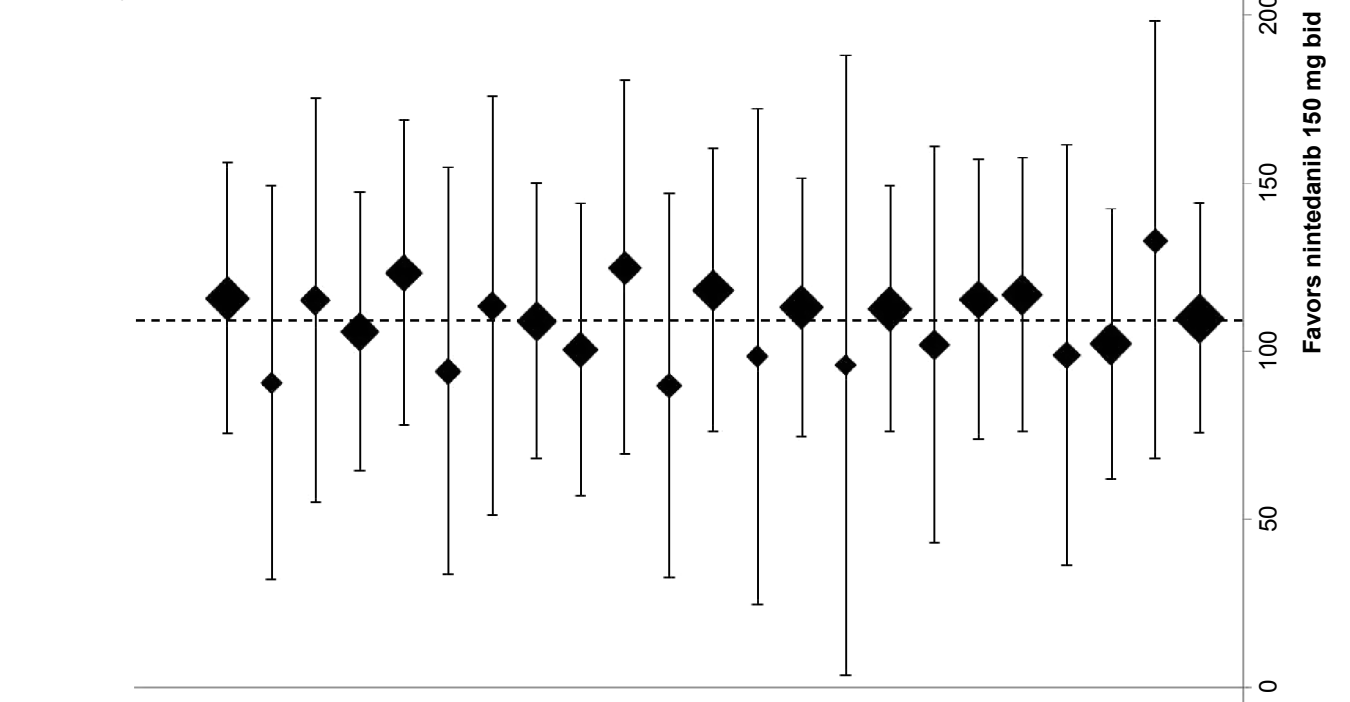

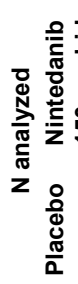

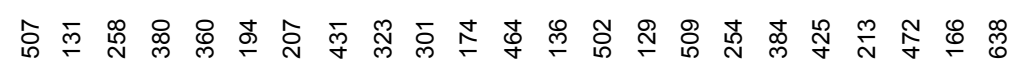

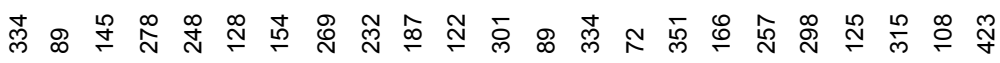

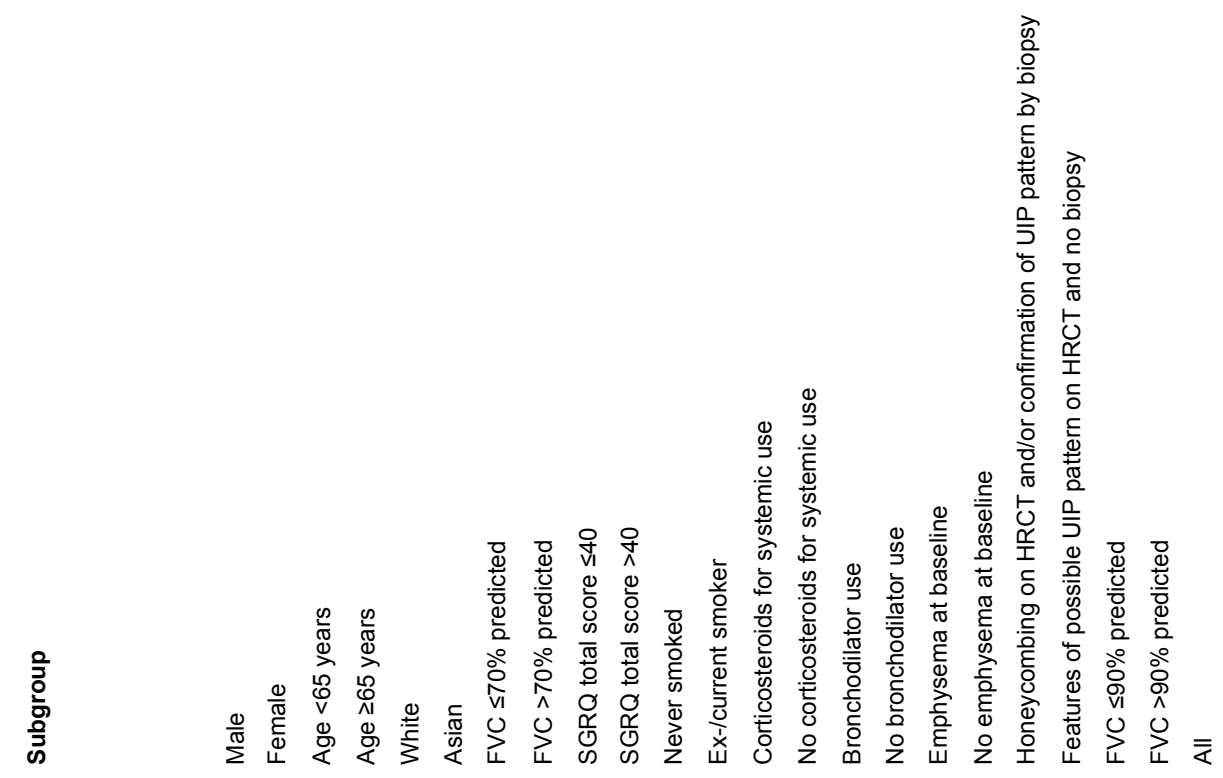




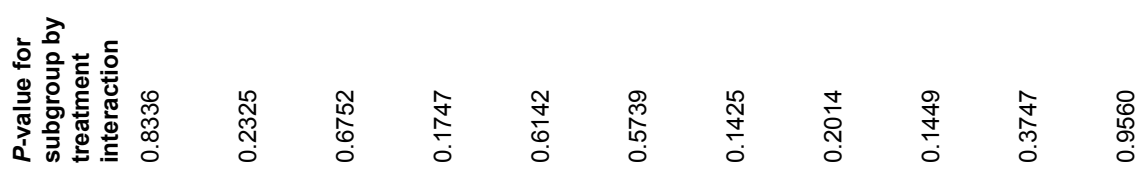

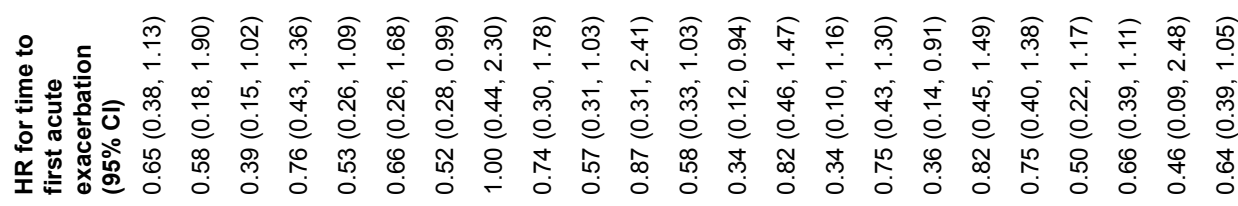

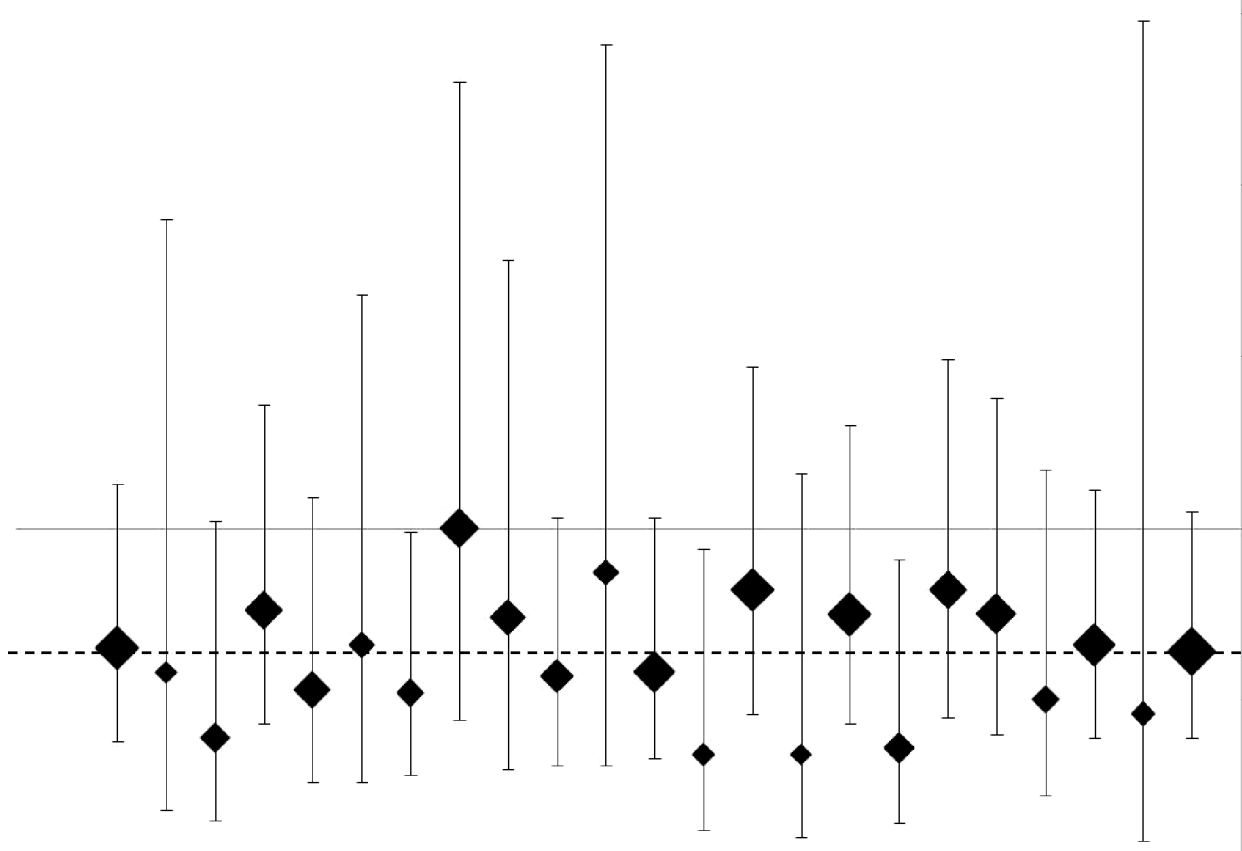

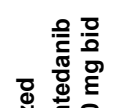

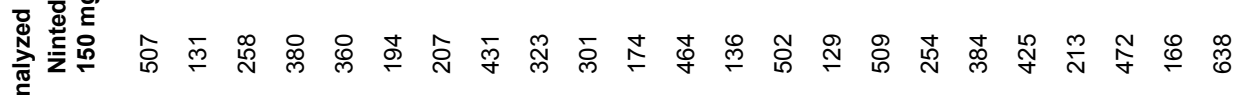
离 $\frac{8}{8}$

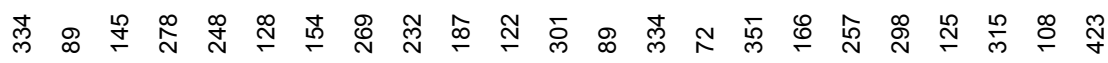

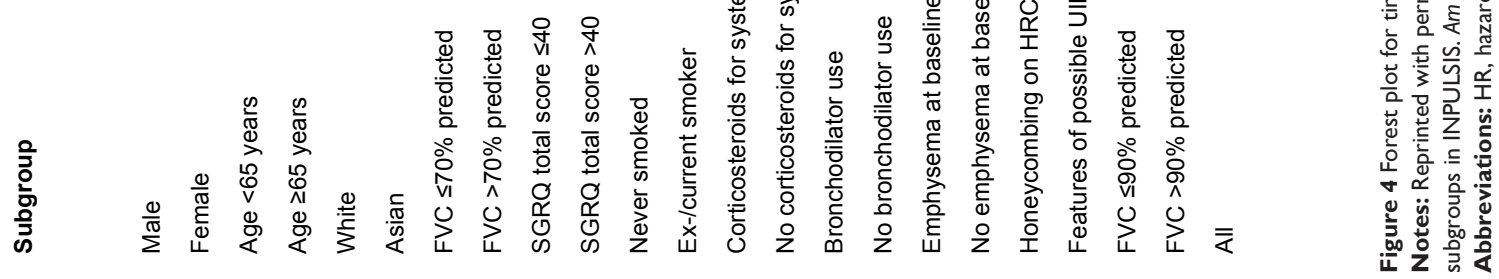


of patients treated with nintedanib compared to $18 \%$ in the placebo group. Diarrhea adverse events were mild to moderate in intensity in the vast majority of patients and led to premature treatment discontinuation in fewer than $5 \%$ of nintedanib-treated patients. ${ }^{30}$ More than $90 \%$ of eligible patients $(734 / 807)$ chose to receive open-label nintedanib in the ongoing INPULSIS ${ }^{\circledR}$-ON extension trial, which recently confirmed the long-term safety and tolerability profile of nintedanib in an interim analysis..$^{93}$

\section{Conclusion}

In the last decade, growing knowledge of pathogenetic mechanisms underlying IPF has led to new treatments for this fatal disease. Nintedanib is a potent tyrosine kinase inhibitor with a distinct specificity targeting growth factors involved in fibrotic changes in the lungs of patients with IPF. The clinical efficacy of nintedanib in slowing disease progression has been shown in three clinical trials, resulting in the approval of this medication as a treatment for IPF independent of the extent of lung functional impairment.

\section{Acknowledgments}

Editorial assistance (edit by native speaker) was provided by Wendy Morris of Fleishman-Hillard Group, London, UK. The authors are responsible for all content decisions.

\section{Disclosure}

Francesco Bonella reports receipt of travel grants, research grants, speaker honoraria, and fees for serving on advisory boards from Boehringer Ingelheim, InterMune, Roche, Gilead, Centocor, and Serendex. Susanne Stowasser and Lutz Wollin are employees of Boehringer Ingelheim. The authors report no other conflicts of interest in this work.

\section{References}

1. Bjoraker JA, Ryu JH, Edwin MK, et al. Prognostic significance of histopathologic subsets in idiopathic pulmonary fibrosis. Am J Respir Crit Care Med. 1998;157(1):199-203.

2. Hutchinson J, Fogarty A, Hubbard R, McKeever T. Global incidence and mortality of idiopathic pulmonary fibrosis: a systematic review. Eur Respir J. 2015;46(3):795-806.

3. Raghu G, Chen SY, Yeh WS, et al. Idiopathic pulmonary fibrosis in US Medicare beneficiaries aged 65 years and older: incidence, prevalence, and survival, 2001-11. Lancet Respir Med. 2014;2(7):566-572.

4. Navaratnam V, Fleming KM, West J, et al. The rising incidence of idiopathic pulmonary fibrosis in the U.K. Thorax. 2011;66(6):462-467.

5. Raghu G, Collard HR, Egan JJ, et al. An official ATS/ERS/JRS/ALAT statement: idiopathic pulmonary fibrosis: evidence-based guidelines for diagnosis and management. Am J Respir Crit Care Med. 2011;183(6): 788-824.

6. Ohshimo S, Bonella F, Cui A, et al. Significance of bronchoalveolar lavage for the diagnosis of idiopathic pulmonary fibrosis. Am J Respir Crit Care Med. 2009;179(11):1043-1047.
7. Casoni GL, Tomassetti S, Cavazza A, et al. Transbronchial lung cryobiopsy in the diagnosis of fibrotic interstitial lung diseases. PLoS One. 2014;9(2):e86716.

8. Kropski JA, Pritchett JM, Mason WR, et al. Bronchoscopic cryobiopsy for the diagnosis of diffuse parenchymal lung disease. PLoS One. 2013;8(11):e78674.

9. Selman M, Pardo A. Stochastic age-related epigenetic drift in the pathogenesis of idiopathic pulmonary fibrosis. Am J Respir Crit Care Med. 2014;190(12):1328-1330.

10. Selman M, Pardo A. Revealing the pathogenic and aging-related mechanisms of the enigmatic idiopathic pulmonary fibrosis. An integral model. Am J Respir Crit Care Med. 2014;189(10):1161-1172.

11. Spagnolo P, Grunewald J, du Bois RM. Genetic determinants of pulmonary fibrosis: evolving concepts. Lancet Respir Med. 2014;2(5): 416-428.

12. Peljto AL, Zhang Y, Fingerlin TE, et al. Association between the MUC5B promoter polymorphism and survival in patients with idiopathic pulmonary fibrosis. JAMA. 2013;309(21):2232-2239.

13. Noth I, Zhang Y, Ma SF, et al. Genetic variants associated with idiopathic pulmonary fibrosis susceptibility and mortality: a genome-wide association study. Lancet Respir Med. 2013;1(4):309-317.

14. Campo I, Zorzetto M, Bonella F. Facts and promises on lung biomarkers in interstitial lung diseases. Expert Rev Respir Med. 2015;9(4): $437-457$.

15. Tzouvelekis A, Bonella F, Spagnolo P. Update on therapeutic management of idiopathic pulmonary fibrosis. Ther Clin Risk Manag. 2015; 11:359-370.

16. Kim DS, Park JH, Park BK, Lee JS, Nicholson AG, Colby T. Acute exacerbation of idiopathic pulmonary fibrosis: frequency and clinical features. Eur Respir J. 2006;27(1):143-150.

17. Song JW, Hong SB, Lim CM, Koh Y, Kim DS. Acute exacerbation of idiopathic pulmonary fibrosis: incidence, risk factors and outcome. Eur Respir J. 2011;37(2):356-363.

18. Cerri S, Spagnolo P, Luppi F, Richeldi L. Management of idiopathic pulmonary fibrosis. Clin Chest Med. 2012;33(1):85-94.

19. Lee JS, McLaughlin S, Collard HR. Comprehensive care of the patient with idiopathic pulmonary fibrosis. Curr Opin Pulm Med. 2011;17(5): 348-354.

20. Nishiyama O, Kondoh Y, Kimura T, et al. Effects of pulmonary rehabilitation in patients with idiopathic pulmonary fibrosis. Respirology. 2008; 13(3):394-399.

21. Vainshelboim B, Oliveira J, Fox BD, Soreck Y, Fruchter O, Kramer MR. Long-term effects of a 12-week exercise training program on clinical outcomes in idiopathic pulmonary fibrosis. Lung. 2015;193(3): 345-354.

22. Vainshelboim B, Oliveira J, Yehoshua L, et al. Exercise training-based pulmonary rehabilitation program is clinically beneficial for idiopathic pulmonary fibrosis. Respiration. 2014;88(5):378-388.

23. Egan JJ. Follow-up and nonpharmacological management of the idiopathic pulmonary fibrosis patient. Eur Respir Rev. 2011;20(120):114-117.

24. Yusen RD, Edwards LB, Kucheryavaya AY, et al. The registry of the International Society for Heart and Lung Transplantation: thirtyfirst adult lung and heart-lung transplant report - 2014; focus theme: retransplantation. J Heart Lung Transplant. 2014;33(10):1009-1024.

25. Russo MJ, Iribarne A, Hong KN, et al. High lung allocation score is associated with increased morbidity and mortality following transplantation. Chest. 2010;137(3):651-657.

26. Gottlieb J. Lung transplantation for interstitial lung diseases. Curr Opin Pulm Med. 2014;20(5):457-462.

27. Schaffer JM, Singh SK, Reitz BA, Zamanian RT, Mallidi HR. Single- vs double-lung transplantation in patients with chronic obstructive pulmonary disease and idiopathic pulmonary fibrosis since the implementation of lung allocation based on medical need. JAMA. 2015;313(9):936-948.

28. Idiopathic Pulmonary Fibrosis Clinical Research Network, Martinez FJ, de Andrade JA, Anstrom KJ, King TE Jr, Raghu G. Randomized trial of acetylcysteine in idiopathic pulmonary fibrosis. $N$ Engl $J$ Med. 2014;370(22):2093-2101. 
29. King TE Jr, Bradford WZ, Castro-Bernardini S, et al. A phase 3 trial of pirfenidone in patients with idiopathic pulmonary fibrosis. $N$ Engl $J$ Med. 2014;370(22):2083-2092.

30. Richeldi L, du Bois RM, Raghu G, et al. Efficacy and safety of nintedanib in idiopathic pulmonary fibrosis. N Engl J Med. 2014;370(22):2071-2082.

31. Raghu G, Rochwerg B, Zhang Y, et al. An official ATS/ERS/JRS/ ALAT clinical practice guideline: treatment of idiopathic pulmonary fibrosis: executive summary: an update of the 2011 clinical practice guidelines. Am J Respir Crit Care Med. 2015;192(2):238-248.

32. Schaefer CJ, Ruhrmund DW, Pan L, Seiwert SD, Kossen K. Antifibrotic activities of pirfenidone in animal models. Eur Respir Rev. 2011; 20(120):85-97.

33. Hilberg O, Simonsen U, du Bois R, Bendstrup E. Pirfenidone: significant treatment effects in idiopathic pulmonary fibrosis. Clin Respir J. 2012; 6(3):131-143.

34. Azuma A, Nukiwa T, Tsuboi E, et al. Double-blind, placebo-controlled trial of pirfenidone in patients with idiopathic pulmonary fibrosis. Am J Respir Crit Care Med. 2005;171(9):1040-1047.

35. Noble PW, Albera C, Bradford WZ, et al. Pirfenidone in patients with idiopathic pulmonary fibrosis (CAPACITY): two randomised trials. Lancet. 2011;377(9779):1760-1769.

36. Taniguchi H, Ebina M, Kondoh Y, et al. Pirfenidone in idiopathic pulmonary fibrosis. Eur Respir J. 2010;35(4):821-829.

37. Stopfer P, Rathgen K, Bischoff D, et al. Pharmacokinetics and metabolism of BIBF 1120 after oral dosing to healthy male volunteers. Xenobiotica. 2011;41(4):297-311.

38. Stopfer P, Roth W, Mross K, et al. Pharmacokinetic characterization of BIBF1120, an orally active triple angiokinase inhibitor (VEGFR, PDGFR, FGFR) in advanced cancer patients. Eur J Cancer. 2015; 4(Suppl 26):A73.

39. Mross K, Stefanic M, Gmehling D, et al. Phase I study of the angiogenesis inhibitor BIBF 1120 in patients with advanced solid tumors. Clin Cancer Res. 2010;16(1):311-319.

40. Okamoto I, Miyazaki M, Takeda M, et al. Tolerability of nintedanib (BIBF 1120) in combination with docetaxel: a phase 1 study in Japanese patients with previously treated non-small-cell lung cancer. $J$ Thorac Oncol. 2015;10(2):346-352.

41. Kropff M, Kienast J, Bisping G, et al. An open-label dose-escalation study of BIBF 1120 in patients with relapsed or refractory multiple myeloma. Anticancer Res. 2009;29(10):4233-4238.

42. Doebele RC, Conkling P, Traynor AM, et al. A phase I, open-label dose-escalation study of continuous treatment with BIBF 1120 in combination with paclitaxel and carboplatin as first-line treatment in patients with advanced non-small-cell lung cancer. Ann Oncol. 2012;23(8): 2094-2102.

43. Ellis PM, Kaiser R, Zhao Y, Stopfer P, Gyorffy S, Hanna N. Phase I open-label study of continuous treatment with BIBF 1120, a triple angiokinase inhibitor, and pemetrexed in pretreated non-small cell lung cancer patients. Clin Cancer Res. 2010;16(10):2881-2889.

44. Bousquet G, Alexandre J, Le Tourneau C, et al. Phase I study of BIBF 1120 with docetaxel and prednisone in metastatic chemo-naive hormone-refractory prostate cancer patients. Br J Cancer. 2011;105(11):1640-1645.

45. du Bois A, Huober J, Stopfer P, et al. A phase I open-label doseescalation study of oral BIBF 1120 combined with standard paclitaxel and carboplatin in patients with advanced gynecological malignancies. Ann Oncol. 2010;21(2):370-375.

46. Ogura T, Taniguchi H, Azuma A, et al. Safety and pharmacokinetics of nintedanib and pirfenidone in idiopathic pulmonary fibrosis. Eur Respir J. 2015;45(5):1382-1392.

47. Reck M, Kaiser R, Eschbach C, et al. A phase II double-blind study to investigate efficacy and safety of two doses of the triple angiokinase inhibitor BIBF 1120 in patients with relapsed advanced non-small-cell lung cancer. Ann Oncol. 2011;22(6):1374-1381.

48. Van Cutsen E, Prenen H, Guillen-Ponce C, et al. A phase I/II, openlabel, randomized study of BIBF 1120 Plus mFOLFOX6 compared to bevacizumab plus mFOLFOX6 in patients with metastatic colorectal cancer. Eur J Cancer. 2011;47(Suppl 2):14LBA.
49. Eisen T, Shparyk Y, Macleod N, et al. Effect of small angiokinase inhibitor nintedanib (BIBF 1120) on QT interval in patients with previously untreated, advanced renal cell cancer in an open-label, phase II study. Invest New Drugs. 2013;31(5):1283-1293.

50. Roth GJ, Binder R, Colbatzky F, et al. Nintedanib: from discovery to the clinic. J Med Chem. 2015;58(3):1053-1063.

51. Hilberg F, Roth GJ, Krssak M, et al. BIBF 1120: triple angiokinase inhibitor with sustained receptor blockade and good antitumor efficacy. Cancer Res. 2008;68(12):4774-4782.

52. Wollin L, Wex E, Pautsch A, et al. Mode of action of nintedanib in the treatment of idiopathic pulmonary fibrosis. Eur Respir J. 2015;45: 1434-1445

53. Clark JG, Madtes DK, Raghu G. Effects of platelet-derived growth factor isoforms on human lung fibroblast proliferation and procollagen gene expression. Exp Lung Res. 1993;19(3):327-344.

54. Antoniades HN, Bravo MA, Avila RE, et al. Platelet-derived growth factor in idiopathic pulmonary fibrosis. J Clin Invest. 1990;86(4):1055-1064.

55. Bonner JC. Regulation of PDGF and its receptors in fibrotic diseases. Cytokine Growth Factor Rev. 2004;15(4):255-273.

56. Pan LH, Yamauchi K, Uzuki M, et al. Type II alveolar epithelial cells and interstitial fibroblasts express connective tissue growth factor in IPF. Eur Respir J. 2001;17(6):1220-1227.

57. Khalil N, O'Connor RN, Unruh HW, et al. Increased production and immunohistochemical localization of transforming growth factor-beta in idiopathic pulmonary fibrosis. Am J Respir Cell Mol Biol. 1991;5(2): $155-162$.

58. Piguet PF, Ribaux C, Karpuz V, Grau GE, Kapanci Y. Expression and localization of tumor necrosis factor-alpha and its mRNA in idiopathic pulmonary fibrosis. Am J Pathol. 1993;143(3):651-655.

59. Katzenstein AL, Myers JL. Idiopathic pulmonary fibrosis: clinical relevance of pathologic classification. Am J Respir Crit Care Med. 1998; 157(4 Pt 1):1301-1315.

60. Abdollahi A, Li M, Ping G, et al. Inhibition of platelet-derived growth factor signaling attenuates pulmonary fibrosis. J Exp Med. 2005;201(6): 925-935.

61. Aono $\mathrm{Y}$, Nishioka $\mathrm{Y}$, Inayama $\mathrm{M}$, et al. Imatinib as a novel antifibrotic agent in bleomycin-induced pulmonary fibrosis in mice. Am J Respir Crit Care Med. 2005;171(11):1279-1285.

62. Li M, Abdollahi A, Gröne HJ, Lipson KE, Belka C, Huber PE. Late treatment with imatinib mesylate ameliorates radiation-induced lung fibrosis in a mouse model. Radiat Oncol. 2009;4:66.

63. Rice AB, Moomaw CR, Morgan DL, Bonner JC. Specific inhibitors of platelet-derived growth factor or epidermal growth factor receptor tyrosine kinase reduce pulmonary fibrosis in rats. Am J Pathol. 1999; 155(1):213-221.

64. Vuorinen K, Gao F, Oury TD, Kinnula VL, Myllärniemi M. Imatinib mesylate inhibits fibrogenesis in asbestos-induced interstitial pneumonia. Exp Lung Res. 2007;33(7):357-373.

65. Inoue Y, King TE Jr, Barker E, Daniloff E, Newman LS. Basic fibroblast growth factor and its receptors in idiopathic pulmonary fibrosis and lymphangioleiomyomatosis. Am J Respir Crit Care Med. 2002;166(5): 765-773.

66. Hetzel M, Bachem M, Anders D, Trischler G, Faehling M. Different effects of growth factors on proliferation and matrix production of normal and fibrotic human lung fibroblasts. Lung. 2005;183(4): 225-237.

67. Yu ZH, Wang DD, Zhou ZY, He SL, Chen AA, Wang J. Mutant soluble ectodomain of fibroblast growth factor receptor-2 IIIc attenuates bleomycin-induced pulmonary fibrosis in mice. Biol Pharm Bull. 2012;35(5):731-736.

68. Gupte VV, Ramasamy SK, Reddy R, et al. Overexpression of fibroblast growth factor-10 during both inflammatory and fibrotic phases attenuates bleomycin-induced pulmonary fibrosis in mice. Am J Respir Crit Care Med. 2009;180(5):424-436.

69. Deterding RR, Havill AM, Yano T, et al. Prevention of bleomycininduced lung injury in rats by keratinocyte growth factor. Proc Assoc Am Physicians. 1997;109(3):254-268. 
70. Shimbori C, Bellaye PS, Gauldie J, et al. Fibroblast growth factor-1 attenuates TGF- $\beta 1$-induced lung fibrosis by regulating TGF- $\beta 1$ signaling. Am J Respir Crit Care Med. 2015;191:A2347.

71. Hostettler KE, Zhong J, Papakonstantinou E, et al. Anti-fibrotic effects of nintedanib in lung fibroblasts derived from patients with idiopathic pulmonary fibrosis. Respir Res. 2014;15:157.

72. Hamada N, Kuwano K, Yamada M, et al. Anti-vascular endothelial growth factor gene therapy attenuates lung injury and fibrosis in mice. J Immunol. 2005;175(2):1224-1231.

73. King TE Jr, Pardo A, Selman M. Idiopathic pulmonary fibrosis. Lancet. 2011;378(9807):1949-1961.

74. Renzoni EA. Neovascularization in idiopathic pulmonary fibrosis: too much or too little? Am J Respir Crit Care Med. 2004;169(11):1179-1180.

75. Farkas L, Kolb M. Pulmonary microcirculation in interstitial lung disease. Proc Am Thorac Soc. 2011;8(6):516-521.

76. Farkas L, Gauldie J, Voelkel NF, Kolb M. Pulmonary hypertension and idiopathic pulmonary fibrosis: a tale of angiogenesis, apoptosis, and growth factors. Am J Respir Cell Mol Biol. 2011;45(1):1-15.

77. Cui A, Anhenn O, Theegarten D, et al. Angiogenic and angiostatic chemokines in idiopathic pulmonary fibrosis and granulomatous lung disease. Respiration. 2010:80(5):372-378.

78. Roodhart JM, Langenberg MH, Witteveen E, Voest EE. The molecular basis of class side effects due to treatment with inhibitors of the VEGF/ VEGFR pathway. Curr Clin Pharmacol. 2008;3(2):132-143.

79. Arrondeau J, Huillard O, Tlemsani C, et al. Investigational therapies up to Phase II which target PDGF receptors: potential anti-cancer therapeutics. Expert Opin Investig Drugs. 2015;24(5):673-687.

80. Wöhrle S, Bonny O, Beluch N, et al. FGF receptors control vitamin D and phosphate homeostasis by mediating renal FGF-23 signaling and regulating FGF-23 expression in bone. J Bone Miner Res. 2011;26(10): 2486-2497.

81. Wollin L, Maillet I, Quesniaux V, Holweg A, Ryffel B. Antifibrotic and anti-inflammatory activity of the tyrosine kinase inhibitor nintedanib in experimental models of lung fibrosis. J Pharmacol Exp Ther. 2014; 349(2):209-220.

82. Ackermann M, Kim YO, Schuppan D, et al. Effects of nintedanib on the microvascular architecture in a bleomycin-induced pulmonary fibrosis model. Am J Respir Crit Care Med. 2015;191:A4395.
83. Rieg AD, Wollin L, Krabbe J, Uhlig S, Martin C. Vasorelaxant properties of nintedanib in the murine pulmonary circulation. Am J Respir Crit Care Med. 2015;191:A1956.

84. Richeldi L, Costabel U, Selman M, et al. Efficacy of a tyrosine kinase inhibitor in idiopathic pulmonary fibrosis. $N$ Engl J Med. 2011; 365(12):1079-1087.

85. Cottin V, Taniguchi H, Richeldi L, et al. Effect of baseline emphysema on reduction in FVC decline with nintedanib in the INPULSIS trials. Paper presented at: ICLAF 2014, 18th International Colloquium on Lung and Airway Fibrosis (ICLAF), September 20-24, 2014, Mont Tremblant, Canada. Available from: http://www.iclaf.com/conference/index. php/2014/ICLAF/paper/view/151. Accessed November 4, 2015.

86. Kolb M, Richeldi L, Kimura T, Stowasser S, Hallmann C, du Bois RM. Effect of baseline FVC on decline in lung function with nintedanib in patients with IPF: results from the INPULSIS trials. Am J Respir Crit Care Med. 2015;191:A1021.

87. Raghu G, Wells A, Nicholson AG, et al. Consistent effect of nintedanib on decline in FVC in patients across subgroups based on HRCT diagnostic criteria: results from the INPULSIS trials in IPF. Am J Respir Crit Care Med. 2015;191:A1022.

88. Kolb M, Collard HR, Stowasser S, Girard M, Schlenker-Herceg R, Richeldi L. Sensitivity analyses from the INPULSIS trials of nintedanib. Eur Respir J. 2014;44(Suppl 58):A1908.

89. Cottin V, Taniguchi H, Collard HR, et al. Reduction in disease progression with nintedanib in the INPULSIS trials. Eur Respir J. 2014; 44(Suppl 58):A1906.

90. Costabel U, Inoue Y, Richeldi L, et al. Efficacy of nintedanib in idiopathic pulmonary fibrosis across pre-specified subgroups in INPULSIS. Am J Respir Crit Care Med. Epub September 22, 2015.

91. Richeldi L, Costabel U, Selman M, et al. Efficacy and safety of nintedanib in patients with IPF beyond week 52: data from the Phase II TOMORROW trial. Am J Respir Crit Care Med. 2015;191:A1019.

92. Cottin V. Nintedanib: a new treatment for idiopathic pulmonary fibrosis. Clin Invest. 2015:5:621-632.

93. Crestani B, Ogura T, Pelling K, et al. Interim analysis of nintedanib in an open-label extension of the INPULSIS trials. Eur Respir J. 2015; 46(Suppl 59):OA4495.

\section{Publish your work in this journal}

Drug Design, Development and Therapy is an international, peerreviewed open-access journal that spans the spectrum of drug design and development through to clinical applications. Clinical outcomes, patient safety, and programs for the development and effective, safe, and sustained use of medicines are a feature of the journal, which

\section{Dovepress}

has also been accepted for indexing on PubMed Central. The manuscript management system is completely online and includes a very quick and fair peer-review system, which is all easy to use. Visit http://www.dovepress.com/testimonials.php to read real quotes from published authors. 